\title{
SUPPORT OF BUSINESS INNOVATION IN THE FORM OF TAX BENEFITS FOR R\&D OF ENTREPRENEURS IN SLOVAKIA
}

\author{
Lea Jančičková ${ }^{1}$ \\ Renáta Pakšiová ${ }^{2}$
}

Received: December 21, 2020 / Revised: February 1, 2021 / Accepted: April 2, 2021

(C) Association of Economists and Managers of the Balkans, 2021

\begin{abstract}
Since 2015, the tax advantage of the R\&D of entrepreneurs in Slovakia has been in the form of indirect support of innovation and creativity in companies. It could be a competitive advantage for the entrepreneurs who apply them. They are important on the revenue level, e.g. in the creation of a new product and on the cost level, in streamlining the conduct of business. This article aims to analyze the application of super-deduction in tax due to R\&D carried out by entrepreneurs in Slovakia from the first year and focuses on R\&D in the Slovak Republic from 2015 to 2018. Theoretical interpretations of $R \& D$ in legislative standards at transnational and national levels, different tax policies on innovation and gross domestic spending are defined at the outset. The theoretical background is important from the point of view of understanding the $R \& D$ in the conditions of the Slovak Republic, where the following quantitative research is carried out. As the main method of investigation, we used the quantitative analysis and comparison that we use to compare the increasing number of companies that used the R\&D cost (expenditure) deduction in the context of legal form in the period considered for the years 2015 to 2018 and the amounts of applied super-deduction for individual types of companies. The performed quantitative analysis shows a weak use of the provided income tax relief in the form of super-deduction of costs in connection with the implementation of $R \& D$ by companies in Slovakia, despite the year-on-year growing trend. Due to the relative representation of individual legal forms of entities in Slovakia, according to our research, Limited Liability Companies apply a super-deduction of $R \& D$ costs annually in the period under review. The number of these entities is constantly growing, as is the amount of the super-deduction applied. Based on the findings, we can state that the increased percentage deduction rate had a positive effect on the motivation of entrepreneurs to apply incentives.
\end{abstract}

Keywords: Research, Development, Income tax, Tax super deduction, Creativity.

\section{JEL Classification O32 $\cdot$ L26}

$\triangle \quad$ lea.jancickova@euba.sk

1 University of Economics in Bratislava, Dolnozemská cesta 1, 85235 Bratislava, Slovakia

2 University of Economics in Bratislava, Dolnozemská cesta 1, 85235 Bratislava, Slovakia 


\section{INTRODUCTION}

Companies' investments in research and development are one of the factors that stimulate the economic growth and innovative performance of companies and the state (MacGregor Pelikánová, $2019 b$ ). Under the effort to support the process of increasing the competitiveness of Europe and employment, the Member States have to intensify the efforts to progress in structural reforms and to provide an appropriate e-framework for that (MacGregor Pelikánová \& MacGregor, 2017).

Better use of the European economic and industrial potential as a basic component of the growth and competitiveness program is crucial. A strategic objective is the implementation of policies to support technological and societal innovations using the potentially strong areas and competitive advantages of particular regions and the Member States. A basic precondition for the elaboration of a smart specialization strategy is that the Slovak Republic demonstrates its ability to strategically manage and concentrate permanently limited sources with the aim of sustainable development and develop the country in harmony with principles of smart, sustainable, and inclusive growth to strengthen the competitiveness of the Slovak Republic and the European Union (Turečková \& Nevima, 2020). This is why the strategy and its implementation have to comply with the principles of partnership, communication and participative preparation, approval, implementation, monitoring, and evaluation of results with the involvement of direct and indirect stakeholders (Ministry of the Economy, 2013). Such a procedural approach has resulted in a vision, the objective of which is to stimulate a structural change in the Slovak economy towards growth based on increasing innovation ability and excellence in research and innovation to support the sustainable growth of incomes, employment, and quality of life (Ministry of the Economy, 2013).

R\&D support can be in direct or indirect form. Direct types of support include the provision of public aid in the form of grants and subsidies. Indirect types of support for the development of $R \& D$ can be described as tax incentives in the form of additional deduction of expenses incurred, in the form of a tax credit or preferential treatment for companies. The benefits include exemption royalties or income from the sale of research-related assets or patents, and development. The main goal of tax incentives for R\&D is to support the entrepreneurship sector, supporting the competitiveness of companies, increasing the attractiveness of the home country to foreign multinational companies and their transfer of activities to the land countries. In Slovakia, we include government subsidies as direct support for R\&D and indirect support for tax relief among which we include a super-deduction of R\&D expenditures (costs).

Companies prefer to buy innovations from other countries or carry out the development of these innovations abroad, where better conditions are created for them if the state does not support them, or only weakly supports $R \& D$. The popularity of tax incentives for $R \& D$ in the world is growing. It is being evaluated worldwide effectiveness of impact on innovative technologies by various tools (Bockova \& Zizlavsky, 2016; MacGregor Pelikánová, 2019b). Governments, for the last half-century to the present, have managed a large sum of public funding to expand the scientific and technical knowledge base to reduce uncertainty, replace inefficient markets by sharing risks and costs and suggest ways to overcome their inaccessibility (Cunningham, Gök \& Laredo, 2013). There were various taxes and subsidy measures established to encourage private companies to carry out R\&D projects themselves (David, Hall \& Toole, 2000). For example, from 2000 through 2013, government finances R\&D support instruments accounted for almost $70 \%$ of all R\&D costs carried out in 2006 OECD countries (Appelt et. al., 2016) in the form of grants, the purchase of R\&D services and R\&D tax incentives. Exploring the motivation and impacts on the application of R\&D and innovations by entrepreneurs, including motivation in the form of various external supports, is still actual and important. 
A tax policy harmonization has not succeeded in the European Union either, it has failed to this time and it can be argued that it has never succeeded. Various studies have concluded that the American multinational company requires more thorough research collaboration to disperse R\&D in different countries. The link between R\&D intensity and tax incentives is three to five times greater when the company is not from the same country. Cross-border cooperation helps companies to achieve tax-efficient investments in R\&D (Huang, Krull \& Ziedonis, 2020).

This contribution is divided into four chapters, in which we focus on the theoretical definition of various tax policies on innovation, gross domestic expenditure on R\&D and public policy support. Our research is focused on the analysis of the application of deduction of expenditures on R\&D in the Slovak republic according to the legal form.

In this article, the main objective is to analyze the use of direct tax instruments to relieve R\&D implementation according to the legal forms of companies operating in the Slovak Republic and amounts applied on super deduction.

\section{THROUGH WHAT CHANNELS DO TAX POLICIES SHAPE INNOVATION?}

In this section, we conceptually map the effects of different tax policies on innovation, emphasizing the many channels through which policies can play a role.

Firms in "mobile" industries (e.g., pharmaceutical and high-tech industries) have large amounts of intellectual property and produce goods that are used around the world. Therefore, they are better suited to take advantage of the differences in tax rates across jurisdictions. Firms in these industries can use strategic transfer pricing, shift actual assets, and take advantage of global R\&D tax incentives, among other strategies, to move profits to low-tax countries, thereby reducing their tax burden (De Simone \& Stomberg, 2013).

The main actors for innovation. Innovation is done by firms or individual inventors. These key agents of innovation are represented at the center of the column. Inventors can be self-employed or work in companies' R\&D labs (Akcigit \& Stantcheva, 2020). Inventors and firms can be of varying productivity, i.e., the efficiency with which they convert R\&D and research inputs into innovations (Melecký, 2017; Staníčková, 2014). The way innovation systems are defined has major implications for the balance and mix of policies needed to improve innovation system performance and for the amount of communication and coordination required to create holistic innovation policies (OECD, 2009).

Innovation inputs and actions. The production of quality and quantity of innovation requires inputs. These inputs are either tangible - lab space, equipment, or material resources - or intangible - effort, the skill and know-how of workers, or the efficiency of management. Companies have to choose whether to enter a given market, remain in operation, or exit. They also select their geographic location, which could be in multiple places and different for production or research facilities (Akcigit, Hanley \& Serrano-Velarde, 2013). Innovative metrics allow you to see if you're doing enough activities, more specifically enough of the right types of activities (Kylliäinen, 2018).

General and Specific Tax Policies. The main tax policies that shape innovation can be classified into general tax policies, such as personal income taxes, corporate income taxes, or education subsidies, and more targeted innovation-specific tax policies, such as R\&D tax credits, start-up subsidies, research subsidies for specific types of research and R\&D, and location-specific incentives for firms and inventors. 
Companies that spend money developing new products, processes, or services; or enhancing existing ones, are eligible for R\&D tax relief. If they're spending money on their innovation, they can make an R\&D tax credit claim to receive either a cash payment and/or a Corporation Tax reduction. The scope for identifying $R \& D$ is huge - in fact, it exists in every single sector (Forrest Brown, 2020).

Regarding general tax policy, inventors and firms could in principle be affected by personal and corporate income taxes. For inventors, the personal income tax directly affects the size of their post-tax income. For self-employed inventors, the corporate income tax matters if and when they decide whether to incorporate it or not. For employed inventors and firms, any surplus-sharing implies that both the personal and corporate tax shape the payoffs. The extent to which the corporate income tax will affect firms' R\&D decisions depends on the share of research inputs that can be expensed; with full expensing, corporate income taxes should not affect R\&D investment decisions (Akcigit \& Stantcheva, 2020). The introduction of R\&D Super Deduction in the Czech Republic proved the growth of own R\&D expenditures in the manufacturing industry. It also had a positive impact on SMEs (Bočková \& Meluzín, 2016).

\section{GROSS DOMESTIC SPENDING ON R\&D}

The United Nations have chosen a long-term goal and sustainable development by 2030, strengthening the position of scientific research, and support for innovation. The objectives of the Europe 2020 strategy also lead to a specific goal for R\&D. In the conditions of the Slovak Republic, this is the goal of investing publicly and privately in $R \& D$ in the amount of $1.2 \%$ of gross domestic product. For the European Union, it is worth three percent of the gross domestic product of the countries.

A register of public research institutions has been established. The European Commission has accepted Implementation plan RIS3 SK, which opened the door for companies to draw resources from the European Union for the period from 2014 to 2020 from the Operational Program Research and innovation, which is a major source of the total $€ 2.3$ billion allocated to funding for research, development, and innovation. The program is funded by European Structural and Investment Funds. RIS3 SK develops procedures and processes to meet the missing criteria concerning strengthening research, technological development, innovation, and relevant investment priorities. The implementation plan sets the government of the country as a responsible institution to ensure the implementation of RIS3 SK. The plan establishes a schedule, a timetable of policy measures to be implemented to ensure compliance with legislative and budgetary commitments, a monitoring mechanism in place implemented activities, and a mechanism for assessing the effective use of existing research infrastructure. Most governments use a combination of tax incentives and direct subsidies to support private investment in R\&D. This supports the view that the concept of the instrument is at least as important as the one used and that complementarity should be used. An example of good practice is that $R \& D$ tax incentives should focus on $R \& D$ expenditure (inputs) rather than on the outputs of the R\&D process (i.e. intellectual property income). They should also better target startups, for example by including transfer and/or refund options. (D'Andria, Pontikakis \& Skonieczna, 2018).

Chart 1 shows the gross domestic spending on R\&D in percentage for the years 2010-2018. Gross domestic spending on R\&D is defined as the total expenditure (current and capital) on R\&D carried out by all resident companies, research institutes, universities, and government laboratories, etc., in the country. It includes R\&D funded from abroad but excludes domestic funds for R\&D 
performed outside the domestic economy. This indicator is measured in USD constant prices using 2010 as the base year and Purchasing Power Parities (PPPs) as a percentage of GDP. As we can see from Chart 1, the Slovak Republic in 2010-2018 lags behind neighboring countries and the EU average.

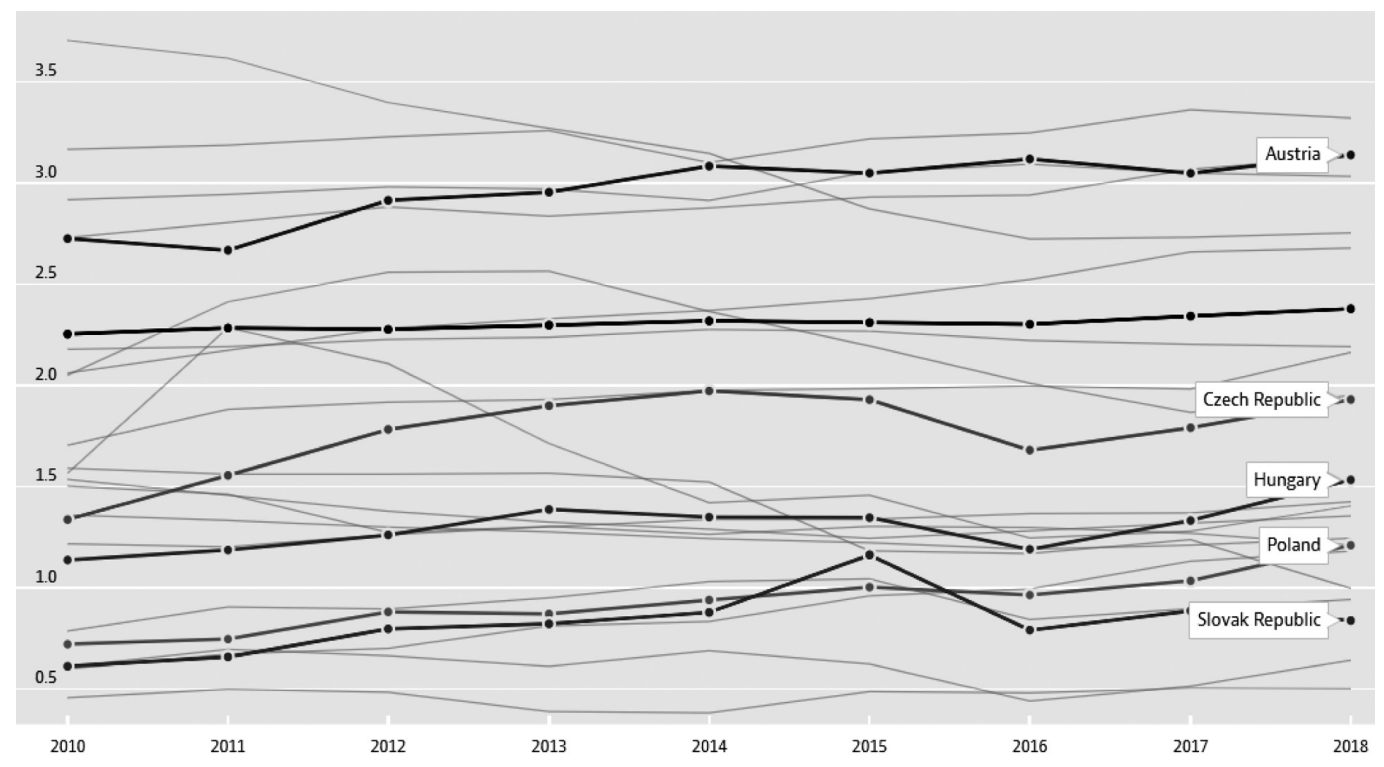

Chart 1. Gross domestic spending on R\&D (total percentage of GDP, 2010-2018)

Source: OECD, 2020

\section{APPLICATION OF DEDUCTION OF EXPENDITURES ON RESEARCH AND DEVELOPMENT IN THE SLOVAK REPUBLIC}

In this part of the paper, we analyze the development of the number of business entities that applied the super-deduction in the individual years of 2015-2018 (Chart 2) and also their structure from the point of view of the legal form of the entities. For 2019, complete information is not yet available due to the postponement of the filing of tax returns of several companies in Slovakia due to the Covid 19.

In research, the processed data is collected and published by the Financial Administration of the Slovak Republic, which, under the authority of the Ministry of Finance, supervises, among other things, compliance with generally binding legal regulations, EU regulations and international treaties, which ensure the implementation of trade policy, customs policy, tax policy. It administers the collection of taxes and its main mission is to effectively collect and administer customs duties and taxes to fulfill the revenue part of the state budget of the Slovak Republic and the budget of the European Union (EU), the protection of the economic interests of the State and the protection of the expenditure part of the State budget of the Slovak Republic (Financial Administration, 2020a). Our research contains data for the Slovak Republic in the period from 2015, when the super-deduction was introduced into our legislation, until 2018, when the data is fully available. Due to the possibility of deferring business tax returns for 2019 due to the ongoing pandemic until October 2020, data for the use of the super-deduction for 2019 is not yet complete, therefore it is not quantitatively evaluated in the contribution. 
We draw all information about companies applying super deduction of R\&D costs from current lists published on the Financial Administration of the Slovak Republic. The Financial Administration of the Slovak Republic collects data on enterprises from completed and filed tax returns, in which companies indicate the number of projects, the objectives of individual projects and the amount of the super deduction they applied in the tax period.

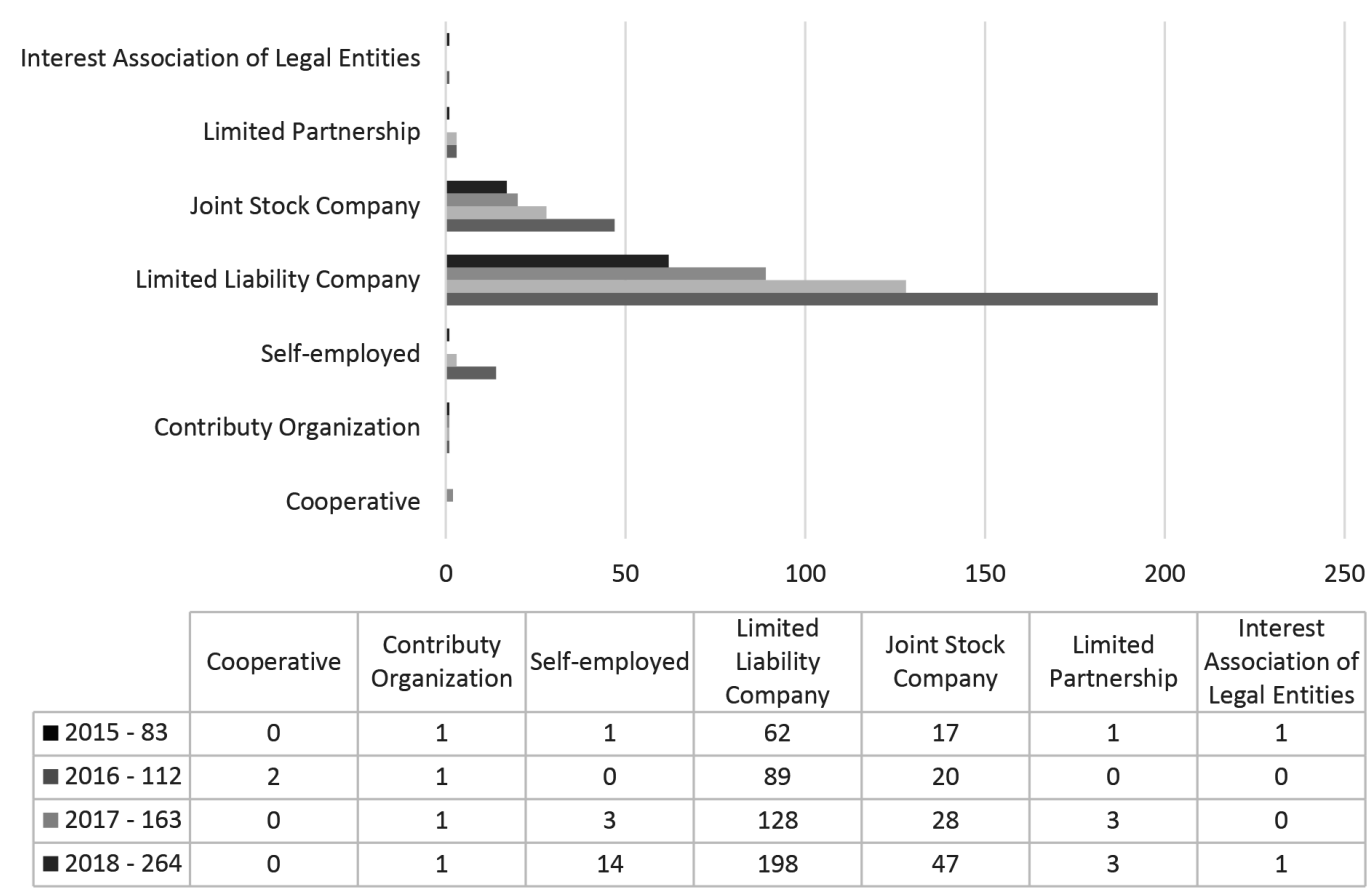

Chart 2. Number of entities that applied the tax super-deduction for R\&D in the Slovak Republic (2015-2018)

Source: Own processing according to Financial Administration (2020b).

The tax super-deduction for R\&D has been introduced in Slovak legislation since 2015. Its amount in that period was $25 \%$. Since 2015 , the tax super-deduction for R\&D has been gradually increasing. Since January 2018, the percentage of super-deduction of expenditures has increased to the level of $100 \%$. In 2019, companies could claim $150 \%$. The amendment to the law makes it possible to deduct up to $200 \%$ from its expenditure on research and development from 2020 onwards. The reason for the gradual increase in super-deduction is the effort to motivate Slovak companies to invest more in research and development. Therefore, it will be interesting to continue research into the impact on the application of supercomputing even after 2018, especially concerning the effect of changes in its application.

The tax super-deduction for R\&D can be used according to Section 30c of Act no. 595/2003 Coll. Income Tax (2020). It represents support from the state for companies but also for sole proprietors who carry out research and development in the subject of their business. A business entity that wants to use a super-deduction must have a written document Research and development project prepared within the deadline for filing a tax return (the change occurs in that it is no longer necessary for the project to be signed before the start of implementation, as is valid until the end 2019, but from 2020 it must be signed by an authorized person by the deadline for filing a tax return). 
Companies and sole traders are obliged to quantify the costs of research and development, and at the same time, they must record the costs separately from other costs. (Vetráková, 2019)

It is clear from Chart 2 that since 2015, when the super-deduction was introduced in the Slovak Republic, the number of entities that applied the deduction has increased every year. A significant increase in entities occurred in 2017 when the deduction was claimed by 51 entities more than in 2016. The reason for this increase may be the fact that the amount of deduction increased from $25 \%$ to $100 \%$, which means greater savings on income tax for entities. The growing trend continued in 2018, the deduction was claimed by 101 entities more than in 2017. Based on our knowledge, a limited liability company is the most frequent legal form of business entity (Chart 2) for all years.

Based on Chart 2, we further focused on the amount of super-deduction applied by individual companies according to legal forms. In the following Charts and Tab, we arranged the individual partial results of the research of companies according to their legal forms in the observed period from 2015 to 2018, as we had comprehensive data for these years.

Table 1. The total amount of the applied super-deduction for R\&D according to legal forms (EUR)

\begin{tabular}{|r|r|r|r|r|r|r|r|}
\cline { 2 - 9 } \multicolumn{1}{c|}{} & Cooperative & $\begin{array}{c}\text { Contributing } \\
\text { Organization }\end{array}$ & $\begin{array}{c}\text { Self-em- } \\
\text { ployed }\end{array}$ & $\begin{array}{c}\text { Limited Li- } \\
\text { ability Com- } \\
\text { pany }\end{array}$ & $\begin{array}{c}\text { Joint Stock } \\
\text { Company }\end{array}$ & $\begin{array}{c}\text { Limited } \\
\text { Partnership }\end{array}$ & $\begin{array}{c}\text { Interest } \\
\text { Association } \\
\text { of Legal } \\
\text { Entities }\end{array}$ \\
\hline $\mathbf{2 0 1 5}$ & 0.00 & $21,291.42$ & $6,166.18$ & $7,165,943.84$ & $2,012,889.92$ & 879.68 & $9,839.74$ \\
\hline $\mathbf{2 0 1 6}$ & $5,137.08$ & $24,651.91$ & 0.00 & $12,352,050.00$ & $4,102,925.10$ & 0.00 & 0.00 \\
\hline $\mathbf{2 0 1 7}$ & 0.00 & $4,135.31$ & $92,666.08$ & $34,078,577.10$ & $5,908,194.02$ & $35,093.72$ & 0.00 \\
\hline $\mathbf{2 0 1 8}$ & 0.00 & $8,802.28$ & $497,434.10$ & $55,715,035.30$ & $22,591,512.20$ & $157,851.40$ & $1,859.75$ \\
\hline
\end{tabular}

Source: Own processing according to Financial Administration (2020b).

Table 1 presents the individual amounts of the applied super-deduction in the observed period according to the legal forms of the companies. In all years, the largest applicator of supercomputing is the legal form of a Limited Liability Company, followed by a Joint Stock Company. On the other hand, we observe a low interest in legal forms such as Cooperative and Interest Association of Legal Entities. A bright factor in the coming years is the constant increase in Self-employed people who were able to promote their project on $R \& D$, even though they have e.g., only 1 employee who had to devise, write and submit the project.

Chart 3 shows the relative total amount of applied super-deduction for research and development in the monitored period according to legal forms of 2015-2018. It is clear, that mostly only two legal forms applied super-deduction for research and development, other legal forms are used rarely, close to $0 \%$.

Limited Liability Companies had the largest share in the application of supercomputing, which we rank among the most used in Slovakia. It does not surprise us that the highest amount of super-compensation was claimed by these companies in the total amount of $€ 109,311,606.00$ and this fact is confirmed to us in each observed year when the amount of the super-deduction increased. The least used legal form, which deals with $R \& D$ and based on this fact can claim a super-deduction of expenses (costs) for R\&D is a Cooperative and Interest Association of Legal Entities. Only $€ 5,137.08$ was claimed by companies in the legal form of a Cooperative during the reporting period. Companies with the legal form of a Limited Liability Company will indeed be 
more interested in $\mathrm{R} \& \mathrm{D}$, but as follows from our analysis, from the beginning of the introduction of super-deduction into the legislation of the Slovak Republic, other legal forms also have the capacity to perform R\&D and so they applied the super-deduction. The amount of the applied super-deduction increases every year and therefore it will be interesting to follow the development in the following years in connection with the situation Covid 19.

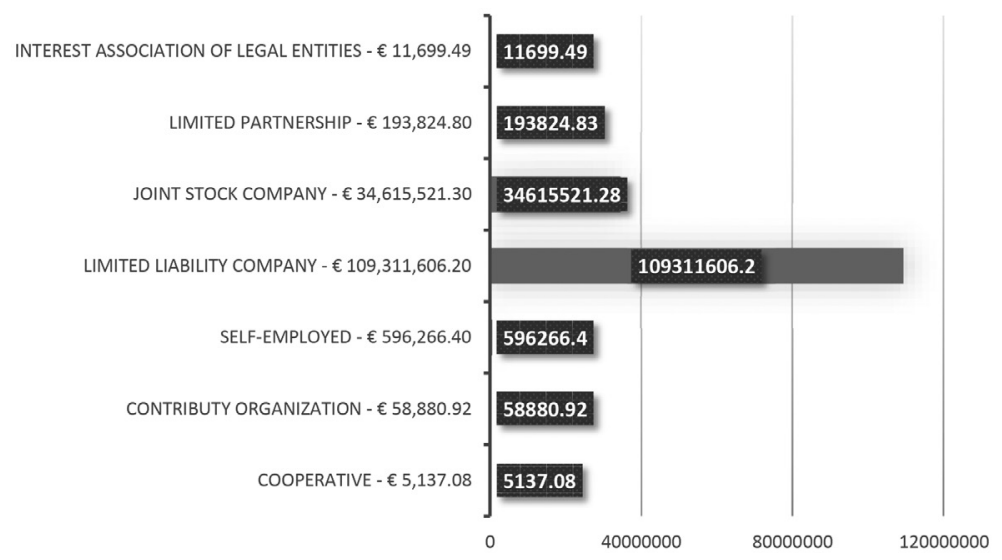

Chart 3. The total amount of applied super-deduction for research and development in the monitored period according to individual legal forms (2015-2018) (\%)

Source: Own processing according to Financial Administration (2020b).

Chart 4 shows the total amount of applied super-deduction for research and development in the monitored period according to separate years 2015-2018. The chart shows an increased yearly trend of the total amount of applied super-deduction for research and development.

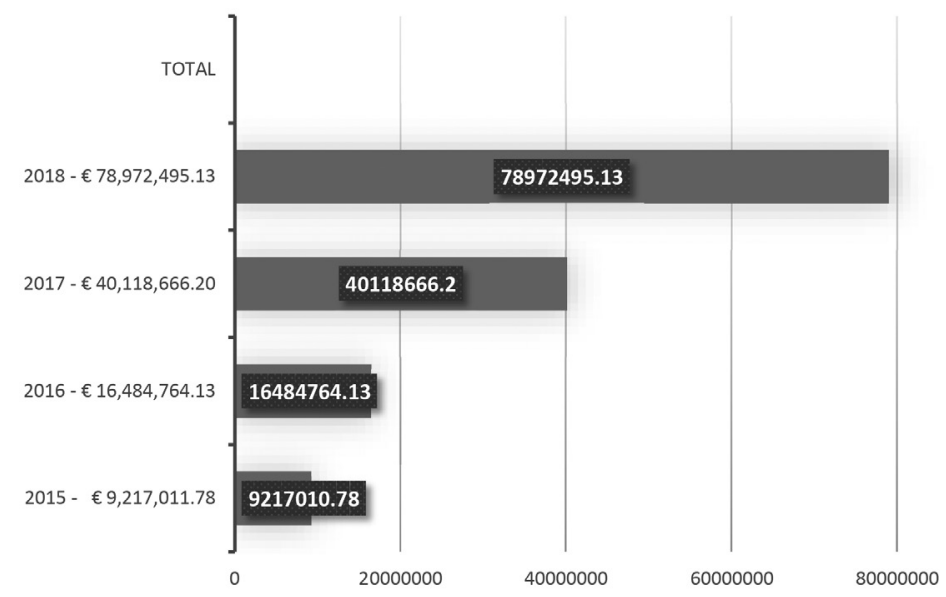

Chart 4. The total amount of applied super-deduction for R\&D in the monitored period (2015-2018) Source: Own processing according to Financial Administration (2020b).

Since the introduction of the super-deduction into the legislation of the Slovak Republic, in 2015 the companies applied a total R\&D deduction of $€ 9,217,011.78$, which represents the lowest value in the observed period, only $6.00 \%$ in the observed period. The amount of the applied su- 
per-deduction increased every year, as evidenced by Chart 4. In 2016, the companies claimed $€ 16,484,764.13$; in $2017 € 40,118,666.20$ and in 2018 the highest value of $€ 78,972,495.13$ which is more than eight times the amount from 2015.

\section{POLICY RATIONALE FOR PUBLIC SUPPORT FOR R\&D}

Government support for business R\&D seeks to encourage firms to invest in knowledge that can result in innovations that transform markets and industries and result in benefits to society. All industries rely extensively on fundamental science and ideas originating from or developed within the government sector itself or publicly-funded institutions, but the support of a financial nature is also provided for some reasons. Most often, the support is provided to firms to correct or alleviate difficulties to appropriate the returns to their investment in new knowledge and shortcomings in the market for the financing of risky projects, especially for small start-up firms without collateral. There are, as widely acknowledged, two major types of market failure (Appelt et. al., 2016):

- Difficulties by firms to fully appropriate the returns to their investment. Returns on R\&D investments are difficult to appropriate by firms as some of the resulting knowledge non-rival and partially non-excludable- will leak out or "spill over" to other firms, to the benefit of society. This leads firms to underinvest in innovation relative to what would be the socially optimal level (OECD, 2016).

- Difficulties in finding external finance, in particular for small firms or startups. Innovation is a highly uncertain activity with large differences between the information available to inventors and that available to investors. This may imply that external capital for innovation will only be available at too high a cost or will not be available at all.

Public support for business R\&D is typically justified as a means of overcoming these market failures. Also, countries may use tax incentives to attract the R\&D activities of multinational corporations (MNEs) which typically account for a substantial share of R\&D expenditure. For example, in some small open economies, such as Ireland, Belgium, and Israel, more than $60 \%$ of business R\&D is accounted for by affiliates of foreign companies (OECD, 2015).

\section{FUTURE RESEARCH DIRECTIONS}

In the Slovak Republic, there is an increasing interest of entities in drawing relief, but these incentives are not used as much as might be expected. This may be due to the extensive administration that the company has to document in order to apply the incentives, and perhaps fears of the subsequent tax inspections, which would not recognize the applied R\&D costs and provide them with sanctions, thus playing a role, leading to the expected tax reliefs being not effective for the company. Exploring these reasons will aim at further research to increase its use, and science and research will be an activity that will be motivated by business entities to carry out more. In further research, we will also focus on monitoring dependencies and examining the territorial and sectoral structure of super-deductible beneficiary companies and the area of R\&D. Analysis of the development of financial indicators of companies that apply incentives to support science and research and their dependence on the amount of super-deduction is in terms of the effectiveness of their use is also an area of future research that can provide scientific evidence for the rationality of their application in companies in the conditions of Slovakia as an EU member. The main methods used in future research are quantitative statistics and the selection of statistical indicators using the financial indicators of enterprises that use super-deduction for R\&D. 


\section{CONCLUSION}

With the gradual transformation of the Slovak economy into an educational economy, it is gradually increasing in our legislation with tools to support research and development in the business environment. One of the most important is undoubtedly an element of research and development super-deduction of expenditure on science and research (PWC Slovakia, 2020).

With the increasing amount of super-deduction for R\&D, it is, therefore, more than obvious that research and innovation represent the future. We can assume that with the increasing percentage rate of super-deduction for R\&D the interest of Slovak entrepreneurs to introduce research and development into their companies will also increase.

By the research results in Slovakia, the number of entities that applied the deduction for R\&D increased over time, but only slightly. The largest increase was recorded in 2018 when the deduction was claimed by 101 entities more than in the previous year 2017. The largest number of business entities applying super-deduction during all years examined is the legal form of a limited liability company. This result can be attributed to the most numerous groups of business entities in the business environment of the Slovak Republic. According to legal forms, the largest user of super-deduction in all years is the legal form of a Limited Liability Company, followed by a Joint Stock Company. On the other hand, we observe a low interest in legal forms, such as Cooperative and Interest Associations of Legal Entities. A clear factor in the coming years is the constant increase in the number of Self-employed people who have been able to promote their project in the field of R\&D, even though they have e.g., only 1 employee who had to design, write and submit the project.

Based on the findings, we can state that the increased percentage deduction rate had a positive effect on the motivation of entrepreneurs to apply incentives. On the other hand, it cannot be said that entrepreneurs who do not apply the super-deduction do not carry out R\&D activities. The intention of the countries should be to increase the attractiveness of super-deduction for R\&D and to improve or simplify smaller businesses, but also others in the development of R\&D projects, reduce the administrative burden and constantly increase the percentage of super-deduction in the Slovak Republic.

\section{ACKNOWLEDGMENT}

This research was supported by the APVV-16-0602.

\section{REFERENCES}

Act No. 595/2003 Coll. Income Tax, as amended.

Akcigit, U., D. Hanley, \& N. Serrano-Velarde (2013). Back to basics: Basic research spillovers, innovation policy, and growth. NBER Working Paper 19473, National Bureau of Economic Research. https://doi.org/10.1093/restud/rdaa061

Akcigit, U., \& S. Stantcheva (2020). Back to basics: Taxation and Innovation: What Do We Know? NBER Working Paper 2020-70, National Bureau of Economic Research.

Appelt, S. et al. (2016), "R\&D Tax Incentives: Evidence on design, incidence and impacts”, OECD Science, Technology and Industry Policy Papers, No. 32, OECD Publishing, Paris. https:// doi.org/10.1787/5jlr8fldqk7j-en

Bočková, N., \& Meluzín, T. (2016). Zpracovatelský průmysl České republiky: Nepřímá podpora výzkumu a vývoje. Scientific Papers of the University of Pardubice.Series D.Faculty of Economics and Administration, (36), pp 42-53. 
Bockova, N., \& Zizlavsky, O. (2016). Innovation and financial performance of company: A study from Czech manufacturing industry. Transformations in business \& economics 15(3) s. 156-175.

Cunningham, P., Gök, A., \& Laredo, Ph. (2013). The Impact of Direct Support to R\&D and Innovation in Firms. Nesta Working Paper 13/03.

D’Andria, D., Pontikakis, D., \& Skonieczna, A., (2018). Towards a European R\&D incentive? An assessment of $R \& D$ provisions under a common corporate tax base. Economics of Innovation and New Technology 27, 531-550. https://doi.org/10.1080/10438599.2017.1376168

David, P., Hall, B., and Toole, A. (2000). Is public R\&D a complement or substitute for private R\&D? A review of the econometric evidence, Research Policy, Volume 29, Issues 4-5, pp. 497-529.

De Simone, L., \& Stomberg, B., (2013). Do investors differentially value tax avoidance of income mobile firms? Working Paper. http://dx.doi.org/10.2139/ssrn.2102903

Financial Administration (2020a). Financial administration. [online]. Retrieved from https:// www.financnasprava.sk/sk/financna-sprava

Financial Administration, (2020b). List of tax subjects who have claimed the deduction of research and development expenses. Retrieved from https://www.financnasprava.sk/sk/elektronicke-sluzby/verejne-sluzby/zoznamy/zoznam-danovych-subjektov-kto

Forrest Brown. (2020). R\&D tax credits explained. Retrieved from https://forrestbrown.co.uk/ rd-tax-credits-explained/

Huang, J., Krull, L., \& Ziedonis, R. (2020). R\&D Investments and Tax Incentives: The Role of Intra-Firm Cross-Border Collaboration. CONTEMPORARY ACCOUNTING RESEARCH Volume: 37, Issue: 4, Pages: 2523-2557. DOI: 10.1111/1911-3846.12588

Kylliäinen, J. (2018). Measuring Innovation - The Definitive Guide to Innovation Management KPIs. Viima Solutions Oy. Retrieved from https://www.viima.com/blog/how-to-measure-innovation-kpis

Macgregor, Pelikánová, R., (2019a). Harmonization of the protection against misleading commercial practices: ongoing divergences in Central European countries. Oeconomia Copernicana, 10(2), 239-252. DOI: 10.24136/oc.2019.012.

Macgregor, Pelikánová, R. (2019b). R\&D expenditure and innovation in the EU and selected member states. JEMI - Journal of Entrepreneurship, Management and Innovation, 2019, 15(1):13-33. doi: 10.7341/20191511.

MacGregor Pelikánová, R. \& MacGregor, R. (2017). European e-Justice Portal - Reality of Electronic One-Stop-Shop for Publication of Financial Statements in the EU. In: Jindřichovská, Irena; Kubičková, Dana. Conference: 5th International Scientific Conference on IFRS Global Rules and Local Use (pp: 98-111), Prague, MU.

Melecký, L. (2017). Meta-analyses of composite indices in the evaluation of European Union territory. In: 20th International Colloquium on Regional Sciences. (pp. 43-51), Brno: Masaryk University.

Ministry of the Economy. (2013). Research and Innovation Strategy for Smart Specialisation of the Slovak Republic. Retrieved from https://www.mhsr.sk/uploads/files/81edIx1h.pdf

OECD (2020), Gross domestic spending on R\&D (indicator). Retrieved from 10.1787/d8b068b4en (Accessed on 24 November 2020)

OECD (2016), OECD Fiscal incentives for R\&D and innovation in a diverse world. OECD Publishing, Paris. Retrieved from https://www.oecd-ilibrary.org/sites/9789264257573-8-en/ index.html?itemId=/content/component/9789264257573-8-en

OECD (2015), OECD Science, Technology and Industry Scoreboard 2015: Innovation for Growth and Society, OECD Publishing, Paris. Retrieved from https://www.oecd-ilibrary.org/science-and-technology/oecd-science-technology-and-industry-scoreboard-2015_sti_scoreboard-2015-en 
OECD (2009), OECD Reviews of Innovation Policy: Mexico 2009. OECD Publishing, Paris. Retrieved from https://www.oecd-ilibrary.org/science-and-technology/oecd-reviews-of-innovation-policy-mexico-2009_9789264075993-en

PWC Slovakia. (2020) R\&D tax super-deduction, Retrieved from https://www.pwc.com/sk/sk/investovanie-na-slovensku/odpocet-vydavkov.html

Staníčková, M., (2014). Competitiveness Factors in Regional Growth: The Case of Central and Eastern European Countries|. In: 2nd International Conference on European Integration (ICEI). (pp. †634-643), † Ostrava: VSB-Technical University Ostrava.

Turečková, K. \& Nevima, J. (2020). The Cost-Benefit Analysis for the Concept of a Smart City: How to Measure the Efficiency of Smart Solutions? Sustainability, 12(7). https://oi. org/10.3390/su12072663.

Vetráková, M., (2019). Daňový superodpočet nákladov na výskum a vývoj.

Retrieved from https://www.ako-uctovat.sk/clanok.php?t=Danovy-superodpocet-nakladov-na-vyskum-a-vyvoj\&idc=396 